Obrazovanje odraslih/Adult Education, ISSN 1512-8784, Broj I - 2 2020., str. I 5-36

UDK: 374.7:379.8.092

Izvorni naučni rad/Original scientific paper

Primljeno/Received: 04. 02. $202 \mathrm{I}$.

Prihvaćeno/Accepted: 22. 03. $202 \mathrm{I}$.

Tamara Nikolić ${ }^{1}$

\title{
Obrazovanje i samopotvrđivanje odraslih u slobodnom vremenu ${ }^{2}$
}

Sažetak: Rad predstavlja prikaz rezultata istraživanja koji se odnose na ispitivanje veze između obrazovanja koje odrasli preduzimaju u slobodnom vremenu, sa jedne strane, i obima, stepena i načina na koji se samopotvrđuju u svom slobodnom vremenu, sa druge. Pod samopotvrđivanjem smo podrazumevali realizaciju ili aktualizaciju sebe kao jedinstvenog bića kroz stepen zadovoljenja različitih potreba, relevantnih sa stanovišta integracije ličnosti. Tako shvaćen pojam samopotvrđivanja, posmatran u kontekstu slobodnog vremena, predstavlja konstituent kvaliteta slobodnog vremena u odraslom dobu. Konkretno, u ovom radu su prikazani rezultati koji se odnose na ispitivanje opšteg nivoa samopotvrđivanja u slobodnom vremenu, kao i doprinosa obrazovnih aktivnosti samopotvrđivanju u slobodnom vremenu. Najznačajniji od njih govore $u$ prilog postojanju univerzalne potrebe za samopotvrđivanjem u slobodnom vremenu. Konkretnije, tiču se samopotvrđivanja u kontekstu emocionalnog blagostanja, predanosti aktivnostima kojim su odrasli birali da se bave u slobodnom vremenu i kreativnosti. Prema dimenzijama samopotvrđivanja, najveći broj ispitanih polaznika obrazovnih aktivnosti se samopotvrđuje u kognitivnom smislu, a najmanji u emocionalnom.

Ključne reči: slobodno vreme, dokoličarsko obrazovanje odraslih, samopotvrđivanje u slobodnom vremenu, dimenzije samopotvrđivanja.

\footnotetext{
${ }^{1}$ Dr Tamara Nikolić je docentica na Odeljenju za pedagogiju i andragogiju Filozofskog fakulteta Univerziteta u Beogradu; e-mail: tamara.nikolic@f.bg.ac.rs

${ }^{2}$ Rad je nastao u okviru projekta Instituta za pedagogiju i andragogiju Filozofskog fakulteta Univerziteta u Beogradu „Modeli procenjivanja i strategije unapređivanja kvaliteta obrazovanja“ (br. 179060), koji finansira Ministarstvo prosvete, nauke i tehnološkog razvoja Republike Srbije.
} 


\section{Uvod}

Istraživanje obrazovanja i samopotvrđivanja odraslih u slobodnom vremenu koje ćemo prikazati u ovom radu je deo šireg istraživanja koje se, najopštije rečeno, ticalo veze između obrazovanja i kvaliteta slobodnog vremena odraslih. ${ }^{3}$ Tom prilikom, kvalitet slobodnog vremena ispitivali smo putem četiri varijable: 1) konzistentnost stvarne i željene obrazovne participacije u slobodnom vremenu, 2) samopotvrđivanje u slobodnom vremenu, 3) zadovoljstvo obrazovnim aktivnostima u slobodnom vremenu i 4) procenom doprinosa obrazovanja kvalitetu slobodnog vremena. Pod kvalitetom slobodnog vremena smo podrazumevali „subjektivni doživljaj dosegnutog nivoa vrednovanog i življenog postignuća u različitim aspektima slobodnog vremena" (Nikolić Maksić 2015:184). Pritom, postignuće smo razumeli kao stepen čovekove celokupne duhovne i materijalne ostvarenosti, podrazumevajući da što je taj stepen viši to se više čovek može smatrati ostvarenim, odnosno, to se u većoj meri približio samoaktualizaciji (Kačavenda-Radić 1992; Kačavenda-Radić, Nikolić Maksić, Ljujić 2011; Nikolić Maksić 2017). Vrednovano i življeno u okviru postignuća predstavljaju vrednosni aspekt - ono što neko vrednuje u slobodnom vremenu, i činjenični aspekt - kako se zaista ponaša i deluje u odnosu na aktivnosti slobodnog vremena.

Pošli smo od pretpostavke da svaka konceptualizacija kvaliteta slobodnog vremena mora uzeti u obzir najmanje dva aspekta:

a) zadovoljstvo aktivnostima slobodnog vremena $\mathrm{i}$

b) stepen samopotvrđivanja u slobodnom vremenu.

Prvi aspekt ukazuje na „kvalitet“ izbora i odluka u vezi sa uključivanjem u određene aktivnosti slobodnog vremena, dok drugi ukazuje na „kvalitet“ zadovoljavanja određenih potreba kroz odabrane aktivnosti u slobodnom vremenu. U prvom slučaju, osoba procenjuje zadovoljstvo okruženjem u kome se odvija slobodno vreme, potrebnim i raspoloživim resursima, kao i njihovim korišćenjem, dok u drugom procenjuje stepen samopotvrđenosti u slobodnom vremenu, iskazujući stavove o slobodnom vremenu, kvalitetu participacije, i uopšte procenjujući svoje slobodno vreme u celini ili kroz pojedine aktivnosti.

\footnotetext{
${ }^{3}$ Istraživanje je sprovedeno za potrebe izrade doktorske disertacije pod nazivom „Obrazovanje kao činilac kvaliteta slobodnog vremena odraslih" odbranjene na Filozofskom fakultetu Univerziteta u Beogradu (videti: Nikolić Maksić, 2015).
} 
U ovom slučaju interesovale su nas obrazovne aktivnosti u slobodnom vremenu. Pod njima podrazumevamo sve one aktivnosti obrazovanja, kao organizovanog vida učenja, koje pojedina odrasla osoba bira i u koje se uključuje u svom slobodnom vremenu. Obrazovanje u slobodnom vremenu sastavni je deo dokoličarskog obrazovanja odraslih (pored obrazovanja za slobodno vreme i obrazovanja profesionalaca za rad u slobodnom vremenu odraslih). Obrazovne aktivnosti u slobodnom vremenu su sastavni deo aktivnosti slobodnog vremena (Kačavenda-Radić 1989; 1992). Kada govorimo o uključivanju u obrazovne aktivnosti u slobodnom vremenu, to nazivamo obrazovno-dokoličarskom participacijom (videti više u: Nikolić Maksić 2015). Pritom, dokolica i slobodno vreme su za nas sinonimi i koristimo ih naizmenično (Nikolić Maksić 2015; 2017).

\section{Samopotvrdivanje kao konstituent kvaliteta slobodnog vremena u odraslom dobu}

Samopotvrdivanje posmatramo kao konstituent kvaliteta slobodnog vremena. Naime, opisujući kvalitet slobodnog vremena, pošli smo od pretpostavke da se on sastoji iz zadovoljstva aktivnostima slobodnog vremena, kao i samopotvrđivanja u slobodnom vremenu. Samopotvrđivanje ili stepen u kome se neko samopotvrđuje u slobodnom vremenu odnosi se na realizaciju ili aktualizaciju sebe kao jedinstvenog bića. U tom smislu se samopotvrđivanje odnosi na stepen zadovoljavanja različitih potreba relevantnih sa stanovišta integracije ličnosti. U slučaju zadovoljstva, u čijoj osnovi se takođe nalazi zadovoljavanje određenih potreba, takve "psihološke“ potrebe čine samo jedan deo zadovoljstva usmerenog na konkretne aktivnosti. S druge strane, kada je reč o samopotvrđivanju, zadovoljstvo je samo jedan manji deo opšte procene zadovoljavanja potreba u ukupnosti slobodnog vremena, odnosno pitanje koliko se neko samopotvrđuje u slobodnom vremenu je mnogo više od prostog zadovoljstva.

Naime, samopotvrđivanje ukazuje i na aspekte za koje ne postoji namera da se realizuju, koje osoba nije nužno osvestila i u odnosu na koje ne postoji unapred formirano očekivanje da će izvesne potrebe koje iza njih stoje biti zadovoljene, kao što je slučaj kada se radi o zadovoljstvu aktivnostima slobodnog vremena. 
Koncept samopotvrđivanja $\mathrm{u}$ istraživanjima dokolice prvi je predstavio Neulinger (1974; 1981, prema: Kačavenda-Radić 1989; Neulinger i Breit 2009), koji je faktorskom analizom izdvojio pet faktora, nazivajući ih „dimenzijama stava prema slobodnom vremenu“, od kojih je značajan faktor - samopotvrđivanje u slobodnom vremenu ili radu (self-definition through leisure or work) ${ }^{4}$. Ovaj faktor se odnosi na stepen samopotvrđivanja ličnosti kroz rad i kroz slobodno vreme, utvrđujući tako odnos važnosti rada i slobodnog vremena u čovekom životu. Samopotvrđivanje u slobodnom/radnom vremenu u kontekstu obrazovanja i slobodnog vremena ispitivala je Kačavenda-Radić (1989); ispitivanjem je utvrđivala da li ispitanik preferira samopotvrđivanje u radnom ili slobodnom vremenu.

Primenjujući modifikovan Neulingerov instrument za merenje preferencije samopotvrđivanja u slobodnom vremenu, Kačavenda-Radić (1992, 1989, 1985) je dobila nalaz koji pokazuje da se gotovo u istom procentu preferira samopotvrđivanje u slobodnom (49,2 \%), kao i u radnom (50,8 \%) vremenu. Kako autorka smatra, ovaj nalaz može biti pokazatelj prisustva tendencije „menjanja tradicionalno ustaljenog značenja rada za samopotvrđivanje čovekove ličnosti, pa prema tome i jačanja značaja slobodnog vremena u životu čoveka“ (1992, str. 59). U kasnijem istraživanju (Kačavenda-Radić 2003), autorka je potvrdila ove rezultate, nalazeći da je, u odnosu na 1980-e godine, kada je samopotvrđivanje bilo u balansu, 1990-ih takođe pretežno ujednačeno, ali nešto veće u korist radnog (57\%) u odnosu na slobodno vreme (43\%). Budući inspirisani ovim nalazima o samopotvrdivanju u slobodnom vremenu, nas je $\mathrm{u}$ ovom istraživanju interesovalo samopotvrđivanje u obrazovno-dokoličarskim aktivnostima u koje su ispitanici uključeni, kao moguć i značajan pokazatelj kvaliteta slobodnog vremena. Ono što je zanimljivo u ovim istraživanjima preferencija samopotvrđivanja jeste rezultat koji ukazuje da nivo obrazovanja nije mnogo bitan. Identičan rezultat autorka je dobila u kasnijem istraživanju obrazovne pripremljenosti stanovništva za turizam (Kačavenda-Radić 2003) ispitujući, između ostalog, povezanost obrazovnog nivoa i samopotvrđivanja u slobodnom vremenu. Prema njenom zaključku, ovakvi nalazi ukazuju na univerzalnost potrebe za samopotvrđivanjem u slobodnom vremenu.

\footnotetext{
${ }^{4}$ Iako Neulinger (1981, prema: Kačavenda-Radić 1989) koristi termin self-definition, mi smo se opredelili da kao engleski termin za samopotvrđivanje u slobodnom vremenu koristimo termin self-affirmation.
} 
U kontekstu kvaliteta slobodnog vremena, čini se da samopotvrđivanje ima još značajniju ulogu u odnosu na alternaciju rad - slobodno vreme. Stepen samopotvrđivanja ukazuje na izražavanje i realizaciju svojih sposobnosti, talenata, ambicija, zadovoljstava, pa time ukazuje i na opšti stepen uživanja u slobodnom vremenu. Ideja o samopotvrđivanju u slobodnom vremenu zasniva se na pretpostavci o slobodnom vremenu kao o kontekstu za generisanje ljudskog rasta, razvoja i transformacije. Ona se direktno odnosi na mogućnost kreiranja slobodnog vremena kao prostora za ekspresivnost i lično izražavanje. Radi se o intenzivnoj uključenosti u aktivnosti slobodnog vremena koja demonstrira nečiji daimon ili istinski poziv (Waterman 1990, prema: Kleiber 1999). Takve aktivnosti, koje su prilika za lično izražavanje, kreiraju doživljaj da je to što neko radi ono za šta je stvoren da radi, kao i osećanje da je on/ona u tom trenutku ono što suštinski jeste.

\section{Pokazatelji samopotvrdivanja u slobodnom vremenu odraslih}

$\mathrm{Na}$ osnovu iznetog, moguće je zaključiti da samopotvrđivanje podrazumeva postojanje određenih faktora koji vode pozitivnom dokoličarskom iskustvu. $\mathrm{U}$ naporu utvrđivanja pokazatelja samopotvrđivanja u slobodnom vremenu, okrenuli smo se koncepcijama „zdravog slobodnog vremena“ (healthy leisure). Zdravo slobodno vreme se shvata kao deo zdravog življenja i promoviše one načine delovanja i donošenja odluka u odnosu na slobodno vreme koje doprinose opštem boljitku i blagostanju čoveka. Godbey (2008) je tako učinio pokušaj identifikovanja nekih karakteristika za koje se može pretpostaviti da čine aktivnost slobodnog vremena „dobrom“ sa stanovišta čovekovog zdravlja. Budući da predlog liste karakteristika nije prošao empirijske provere, autor i sam napominje da ih ne treba nekritički prihvatiti kao opštevažeće i primenjive principe, već je korisnije razmotriti ih u kontekstu svog života i sa aspekta ličnog slobodnog vremena i na taj način postići dublje razumevanje toga šta znači „zdravo“ slobodno vreme. Smatrajući da na dobar način ilustruju ono što bi podrazumevalo samopotvrđivanje u slobodnom vremenu, opisaćemo ukratko te karakteristike. 


\section{Aktivno delovanje}

Zdravo slobodno vreme podrazumeva delovanje, nasuprot pasivnom pristupu i puštanju da situacije i okolnosti deluju na nas. Biti aktivan znači ispoljiti ljudsku volju, pa time slobodno vreme, posmatrano u kontekstu blagostanja i ispunjenja čoveka, zahteva delovanje i aktivni pristup stvarnosti. Može se pretpostaviti da je, ukoliko su svi ostali faktori istovetni, zdravije, na primer, igrati fudbal nego gledati utakmicu. To je zato što su za zdravlje čoveka telesna i duhovna aktivnost ključne. U pomenutom primeru, bavljenje sportom se pozitivno odražava na zdravlje, jer telesni napori ojačavaju snagu, izdržljivost i fizičku spremnost, dok istovremeno mozak formira nove neurone. Nasuprot tome, telesna i duhovna neaktivnost uzrokuju odumiranje niza neurona, hormonski disbalans uzrokovan oslobađanjem manje količine dopamina, loše raspoloženje i osećanje nezadovoljstva.

\section{Ispoljavanje kreativnosti}

Aktivnost slobodnog vremena koja obuhvata mogućnost kreativnog ispoljavanja je zdravija u odnosu na aktivnost koja to ne pretpostavlja. Pod kreativnošću se, u ovom kontekstu, podrazumeva produkovanje novih odgovora koji imaju adekvatan uticaj u okviru datog konteksta (Bishop i Jeanrenaud 1982, prema: Godbey 2008). Tako shvaćen pojam „kreativnosti“ ne znači prosto raditi nešto novo ili drugačije, već podrazumeva efekat koji novi ili drugačiji pristup ima na unapređivanje i poboljšanje izvođenja same aktivnosti. Ukoliko je osoba, prilikom učenja izvođenja dokoličarske aktivnosti do tačke u kojoj može ispoljiti kreativnost, pod stalnom supervizijom onog koji poučava, ona će razviti adekvatne odgovore, ali ne nužno i nove ili drugačije. Tako je za ispoljavanje kreativnosti neophodan balans između disciplinovanosti i slobode u učenju dokoličarskih veština.

\section{Kreiranje značenja}

Pretpostavka koja ističe značaj ovog faktora se sastoji u shvatanju da „zdravo“ slobodno vreme ne može da se odvija u odsustvu značenja. Godbey (2008) 
definiše značenje kao interpretaciju značaja određene situacije, aktivnosti, ideje ili objekta, koja ujedno podrazumeva i referentni okvir za kreiranje odgovora ili reakcije na tu situaciju, aktivnost, ideju ili objekat. Ukoliko takva interpretacija u slobodnom vremenu izostane, teško da može doći do dobrobiti po čovekovo zdravlje. Značenje je svakako drugačije za svakog pojedinca i zavisi od situacije. Tako, kuvanje špageta ima različito značenje za onog ko radi u restoranu da bi zaradio za život i za nekoga ko u svom slobodnom vremenu pozove prijatelje na večeru.

\section{(Pre)davanje}

„Zdravo“ slobodno vreme uključuje i predavanje o aktivnosti, te je ovaj koncept blizak Csíkszentmihályijevom (1999; Csíkszentmihályi \& LeFevre 1989) stanju toka i stanju apsorbovanosti u aktivnost. Osoba se predaje aktivnosti pre nego što pokušava da izvuče korist od te aktivnosti, pa se ujedno radi i o davanju. Ovakvo davanje je, prema Godbeyu (2008) akt poverenja i vere. Razvijajući „zdravo“ ponašanje u slobodnom vremenu, navike koje su dobre sa stanovišta zdravlja i birajući aktivnosti koje to omogućavaju, pojedinac počinje da „veruje“ u njih. Drugim rečima, uključivanje u određene aktivnosti nije zasnovano na kalkulaciji toga koliko košta, čega se odričem, šta dobijam zauzvrat i sl., već se bazira na veri da je određena aktivnost dobra i vredna bavljenja sama po sebi.

\section{Prisustvo optimizma}

Ovaj faktor se zasniva na tezi da su zdravi ljudi generalno optimistični ljudi sa pozitivnim pogledom na sebe, svet i život. Stimulisanje pozitivnog raspoloženja i očekivanja ne samo da čini da se osećamo bolje već pomaže da živimo duži i zdraviji život. Bavljenje aktivnostima u slobodnom vremenu koje podržavaju optimizam i pozitivna osećanja činiće i stepen samopotvrđivanja većim. Naši stavovi prema životu, pa i onom u slobodnom vremenu, su tako u direktnoj vezi sa opštim blagostanjem. 


\section{Postojanje senzualnosti}

Zdravo slobodno vreme uključuje i naše senzacije i osećaje, kao što su dodir, miris, ukus, zvuk i drugi, koji nas povezuju sa zadovoljstvima sveta u kojem obitavamo. Odabrani čulni doživljaji razvijaju našu senzualnost i povećavaju životnu radost. U tom smislu, preporučljivo je i u slobodnom vremenu, gde se očekuje da možemo maksimalno da uživamo u aktivnostima koje nam najviše prijaju, da pristupamo svakom trenutku sa najvećom angažovanošću duha i tela (Preht 2011). Drugim rečima, takav pristup pretpostavlja da živimo u trenutku.

\section{Prisustvo humora}

Ova karakteristika se odnosi na činjenicu da je postojanje i očuvanje smisla za humor u različitim situacijama bitna stavka u očuvanju zdravlja. Kako Godbey (2008) navodi, sposobnost da se smejemo od srca i šalimo na sopstveni račun i na račun različitih životnih situacija je pozitivno povezana sa zdravljem i dugovečnošću. Razigranost u slobodnom vremenu, nasuprot "preozbiljnosti“ koja nosi brige i „rvanje“ sa životnim poteškoćama je, u tom smislu, značajan činilac čovekova blagostanja, pa i kvaliteta njegovog slobodnog vremena.

\section{Ostvarivanje socijalnih odnosa}

Na kraju, ova karakteristika se odnosi na činjenicu da ono što suštinski odlikuje čoveka jeste njegova društvenost i to da je čovek socijalno biće u punom smislu te reči. Verovatno ne postoji značajniji izvor sreće i zadovoljstva od društvenih veza. Ovo je naročito značajno istaći sa stanovišta savremenog života, koji je postao u toj meri ubrzan da nas je učinio produktivnijim, efikasnijim i organizovanijim, ali zato manje spontanim, zadovoljnim i mnogo manje povezanim sa drugim ljudima. Otuđenost, izolacija, osećaj usamljenosti i nedostatak bliskih i intimnih odnosa sa drugima mogu biti štetni sa aspekta zdravlja i blagostanja čoveka. $S$ druge strane, prijateljstvo, intimne veze i porodica mogu stvoriti okolnosti u kojima se čovek oseća srećno i ispunjeno. $\mathrm{Na}$ isti način, biranje aktivnosti u slobodnom vremenu koje podrazumevaju zajedničke doživljaje sa drugim ljudima, prijateljima, partnerom ili decom, doprinose opštoj dobrobiti i zadovoljstvu životom i slobodnim vremenom. 
Ukoliko prihvatimo navedene karakteristike kao indikatore samopotvrđivanja, može se reći da se neko samopotvrđuje u slobodnom vremenu ukoliko:

- aktivno nastupa i deluje kroz aktivnosti u koje se uključuje u slobodnom vremenu,

- u tim aktivnostima ispoljava kreativnost,

- u prilici je da kreira nova značenja u odnosu na dokoličarsko iskustvo,

- predaje se aktivnosti u potpunosti i pruža sebi mogućnost „davanja“ (daje umesto uzima),

- ima osećaj optimizma,

- nastupa kao holističko biće i uključuje širok spektar senzacija za ophođenje sa svetom,

- daje sebi dozvolu da se smeje (razigrani pristup) i ispoljava spontanost kroz igru i improvizaciju (nasuprot ozbiljnom pristupu),

- ima u vidu druge i svoje socijalno okruženje uključuje u ono što radi i čime se bavi.

\section{Doživljaj samopotvrđivanja u slobodnom vremenu kroz dokoličarsko obrazovanje}

Samopotvrđivanje smo u istraživanju posmatrali putem tri varijable: 1) opšti nivo samopotvrđivanja u slobodnom vremenu, 2) opšti doprinos dokoličarskog obrazovanja samopotvrđivanju i 3) doprinos dokoličarskog obrazovanja slobodnom vremenu prema dimenzijama samopotvrđivanja.

\section{Opšti nivo samopotvrdivanja u slobodnom vremenu}

Za potrebe dobijanja podataka o opštem nivou samopotvrđivanja u slobodnom vremenu konstruisali smo skalu sumacionog tipa. Kao što smo objasnili, teorijsku osnovu ove skale činile su postavke i koncept o „zdravom slobodnom vremenu“ koji je predložio Godbey (2008). Tako smo kao indikatore samopotvrđivanja odredili sledeće karakteristike:

- Aktivno delovanje

- Ispoljavanje kreativnosti

- Kreiranje značenja 
- (Pre)davanje

- Prisustvo optimizma

- Postojanje senzualnosti

- Prisustvo humora

- Ostvarivanje socijalnih odnosa

\section{Opšti doprinos dokoličarskog obrazovanja samopotvrdivanju}

Uprkos pretpostavci da uključivanje u obrazovno-dokoličarske aktivnosti predstavlja doprinos kvalitetu slobodnog vremena odraslih, delovalo je značajno postaviti direktno pitanje ispitanicima u kojoj meri procenjuju taj doprinos. Opšti doprinos dokoličarskog obrazovanja samopotvrđivanju smo ispitali kroz zatvoreno pitanje, uz koje smo ponudili petostepenu skalu.

\section{Doprinos dokoličarskog obrazovanja prema dimenzijama samopotvrdivanja}

Određenjem dokoličarskog obrazovanja kao svesnog i sistematskog obrazovanja za i/ili u slobodnom vremenu, čiji su krajnji ciljevi poželjne promene u korišćenju slobodnog vremena (što se može odnositi na verovanja, osećanja, stavove, znanja, veštine i ponašanje), Ruskin (1988, prema: Kačavenda-Radić 1992) objašnjava kako znanja i veštine, kao posledica iskustva, mogućnosti i programa, formiraju stavove i motive koji aktiviraju, ali i proističu iz pojedinih aspekata razvoja. Radi se o sledećim aspektima: intelektualni, fizički, socijalni, estetski i mentalni. Ovakva shvatanja oblikovala su empirijski pristup u našem ranijem istraživanju (Nikolić Maksić 2009) u kome smo ispitivali povezanost ovih aspekata (kao pojedinačnih dimenzija self-koncepta) i obrazovnih aktivnosti u slobodnom vremenu studenata. $S$ obzirom na opšti zaključak istraživanja, prema kome pozitivna povezanost postoji između pojedinih dimenzija self-koncepta i činjeničnog i vrednovanog obrazovanja u slobodnom vremenu (u skladu sa određenom dimenzijom selfkoncepta, mladi odrasli vrednuju obrazovne aktivnosti u slobodnom vremenu, i njima se zaista i bave), delovalo je relevantno uključiti ove dimenzije u kontekstu samopotvrđivanja kroz dokoličarsko obrazovanje. Tako smo ispitali doprinos dokoličarskog obrazovanja prema sledećim dimenzijama samopotvrđivanja:

- samopotvrđivanje u kognitivnoj sferi 
- samopotvrđivanje u odnosu na fizičko-rekreativnu sferu

- samopotvrđivanje u estetsko-umetničkoj sferi

- samopotvrđivanje u socijalnoj sferi

- samopotvrđivanje u emocionalnoj sferi.

\section{Metodološki okvir i rezultati istraživanja}

Ispitanici koji su učestvovali u ovom istraživanju jesu odrasli koji participiraju u dokoličarsko-obrazovnim aktivnostima. Dakle, uzorak čine odrasli koji su u trenutku prikupljanja podataka bili uključeni u neki od organizovanih oblika dokoličarskog obrazovanja u Beogradu, tokom 2013. godine (Nikolić Maksić 2015; 2017).

Doživljaj samopotvrđivanja u slobodnom vremenu ispitivali smo putem ispitivanja opšteg nivoa samopotvrđivanja u slobodnom vremenu, zatim opšteg doprinosa dokoličarskog obrazovanja samopotvrđivanju, kao i ispitivanjem opšteg doprinosa dokoličarskog obrazovanja prema dimenzijama samopotvrđivanja.

Za potrebe ispitivanja opšteg nivoa samoptvrđivanja konstruisali smo skalu samopotvrđivanja, uvtrđujući na osnovu prethodnog teorijskog razmatranja potencijalne indikatore samopotvrđivanja: aktivno delovanje, ispoljavanje kreativnosti, kreiranje značenja, (pre)davanje, prisustvo optimizma, postojanje senzualnosti, prisustvo humora, ostvarivanje socijalnih odnosa - u slobodnom vremenu odraslih.

Radi utvrđivanja prirode postojećih obrazaca unutar većeg broja varijabli (u našem slučaju 24 ajtema na skali opšteg samopotvrđivanja), urađena je faktorska analiza, na osnovu koje je definisan set zajedničkih osnovnih dimenzija (Cohen, Manion \& Morrison 2006). Rezultati faktorske analize predstavljeni su u tabelama br. 1 i br. 2.

Urađena faktorska analiza je (metodom Glavnih komponenti sa Varimaks rotacijom sa Kaiser normalizacijom; faktori su dobijeni iz 7 iteracija) na skali opšteg nivoa samopotvrđivanja u slobodnom vremenu pokazala da postoji pet faktora samopotvrđivanja: samopotvrđivanje kroz opuštanje, predanost, druženje, kreativnost i proaktivnost.

Što se pouzdanosti skale tiče, koeficijent pouzdanosti, Kronbakhova alfa, iznosi 0.926 , što govori o visokoj pouzdanosti skale (videti Tabelu br. 3). 
Tabela br. 1: Faktorska analiza na skali opšteg nivoa samopotvrđivanja u slobodnom vremenu

\begin{tabular}{|c|c|c|c|c|c|}
\hline & $\begin{array}{c}\text { Emocionalni } \\
\text { boljitak }\end{array}$ & Predanost & Druženje & Kreativnost & Proaktivnost \\
\hline $\begin{array}{l}\text { Osećam da u slobodnom vremenu } \\
\text { širim pozitivnu energiju oko sebe. }\end{array}$ & 0.75 & 0.16 & 0.19 & 0.21 & 0.12 \\
\hline $\begin{array}{l}\text { Kada se bavim onim što volim, } \\
\text { osećam prisustvo celim svojim bićem. }\end{array}$ & 0.73 & 0.33 & 0.09 & 0.09 & 0.12 \\
\hline $\begin{array}{l}\text { Dok se bavim aktivnostima u slobodnom vremenu } \\
\text { preplavljuju me pozitivne misli i osećanja. }\end{array}$ & 0.70 & 0.13 & 0.22 & 0.14 & 0.14 \\
\hline $\begin{array}{l}\text { Dok učestvujem u nekoj aktivnosti u slobodnom vremenu, } \\
\text { osećam da sam prisutan/prisutna u trenutku. }\end{array}$ & 0.67 & 0.15 & 0.01 & 0.21 & 0.20 \\
\hline U mom slobodnom vremenu preovladava osećanje optimizma. & 0.61 & 0.32 & 0.21 & 0.14 & 0.22 \\
\hline Krajnje sam spontan/a u svom slobodnom vremenu. & 0.60 & 0.02 & 0.11 & 0.31 & 0.05 \\
\hline $\begin{array}{l}\text { Kada počnem da radim ono što volim, to mi popravi } \\
\text { raspoloženje. }\end{array}$ & 0.59 & 0.30 & 0.03 & 0.10 & 0.13 \\
\hline Osećam se razigrano u slobodnom vremenu. & 0.57 & 0.11 & 0.37 & 0.23 & 0.19 \\
\hline $\begin{array}{l}\text { Aktivnosti koje volim u velikoj meri prate smeh i dobro } \\
\text { raspoloženje. }\end{array}$ & 0.47 & 0.00 & 0.46 & 0.30 & 0.19 \\
\hline $\begin{array}{l}\text { Važno mi je da pridajem značenje onome što radim u } \\
\text { slobodnom vremenu. }\end{array}$ & 0.05 & 0.76 & 0.18 & 0.24 & 0.16 \\
\hline $\begin{array}{l}\text { Aktivnosti koje biram tretiram kao nešto svoje i } \\
\text { posvećujem im se. }\end{array}$ & 0.23 & 0.72 & 0.14 & 0.20 & 0.17 \\
\hline $\begin{array}{l}\text { Potpuno se predam aktivnosti kojom volim da se bavim u } \\
\text { slobodnom vremenu. }\end{array}$ & 0.37 & 0.67 & -0.01 & 0.23 & 0.15 \\
\hline Kada radim ono što volim, osećam da život ima svrhu. & 0.33 & 0.58 & -0.05 & 0.32 & 0.05 \\
\hline $\begin{array}{l}\text { Kada se bavim onim što volim toliko se zanesem da vreme za } \\
\text { mene staje. }\end{array}$ & 0.44 & 0.47 & 0.21 & -0.03 & 0.16 \\
\hline $\begin{array}{l}\text { Ne dozvoljavam da moje slobodno vreme prolazi bezveze, već } \\
\text { biram da radim ono što za mene ima smisao. }\end{array}$ & 0.19 & 0.31 & 0.08 & 0.62 & 0.07 \\
\hline Moje slobodno vreme najčešće uključuje druge ljude. & 0.07 & 0.11 & 0.85 & 0.05 & 0.03 \\
\hline $\begin{array}{l}\text { U slobodnom vremenu volim da ostvarujem bliske i tople } \\
\text { odnose sa drugima. }\end{array}$ & 0.19 & 0.09 & 0.85 & 0.03 & 0.07 \\
\hline Sastavni deo mog slobodnog vremena je upoznavanje ljudi. & 0.19 & 0.07 & 0.83 & 0.09 & 0.06 \\
\hline $\begin{array}{l}\text { Moje slobodno vreme je oslobođeno od ustaljenih obrazaca i } \\
\text { pravila i mogu stvari da radim drugačije i na svoj način. }\end{array}$ & 0.16 & 0.20 & 0.04 & 0.76 & 0.12 \\
\hline $\begin{array}{l}\text { Kontinuirano unapređujem ono čime se bavim u slobodnom } \\
\text { vremenu, otkrivam i dolazim do nečeg novog. }\end{array}$ & 0.29 & 0.21 & 0.16 & 0.66 & 0.27 \\
\hline $\begin{array}{l}\text { U slobodnom vremenu, u stanju sam da ispoljim svoju } \\
\text { kreativnost. }\end{array}$ & 0.29 & 0.14 & 0.08 & 0.63 & 0.29 \\
\hline $\begin{array}{l}\text { Kada je reč o slobodnom vremenu, sebe bih opisao/opisala kao } \\
\text { nekog ko radije deluje, nego nekog na koga se deluje. }\end{array}$ & 0.22 & 0.03 & 0.07 & 0.20 & 0.79 \\
\hline $\begin{array}{l}\text { Bitno mi je da u slobodnom vremenu budem aktivan/aktivna } \\
\text { umesto da se odnosim pasivno prema okruženju i svetu uopšte. }\end{array}$ & 0.24 & 0.19 & 0.18 & 0.15 & 0.76 \\
\hline $\begin{array}{l}\text { Kada radim stvari koje volim, osećam da sam ja agens } \\
\text { sopstvenog života, umesto da zavisim od nekog ili nečeg. }\end{array}$ & 0.15 & 0.30 & -0.01 & 0.18 & 0.73 \\
\hline
\end{tabular}

Metod ekstrakcije: Analiza glavnih komponenti.

Metod rotacije: Varimax sa Kaiser normalizacijom. a. rotacija sprovedena u 7 iteracija 
Tabela br. 2: Faktorska analiza na skali opšteg nivoa samopotvrđivanja u slobodnom vremenu

\begin{tabular}{|c|c|c|c|c|c|c|c|c|c|}
\hline \multicolumn{10}{|c|}{ Ukupno objašnjena varijansa } \\
\hline \multirow{2}{*}{ Komponente } & \multicolumn{3}{|c|}{ Inicijalne Eigenvalues } & \multicolumn{3}{|c|}{$\begin{array}{l}\text { Sume kvadratnih zasićenja dobijenih } \\
\text { ekstrakcijom }\end{array}$} & \multicolumn{3}{|c|}{ Rotirane sume kvadratnih zasićenja } \\
\hline & Total & \% Varijanse & Kumulativni \% & Total & \% Varijanse & Kumulativni \% & Total & \% Varijanse & Kumulativni \% \\
\hline 1 & 9.133 & 38.055 & 38.055 & 9.133 & 38.055 & 38.055 & 4.580 & 19.083 & 19.083 \\
\hline 2 & 2.175 & 9.063 & 47.118 & 2.175 & 9.063 & 47.118 & 2.836 & 11.819 & 30.901 \\
\hline 3 & 1.389 & 5.789 & 52.907 & 1.389 & 5.789 & 52.907 & 2.800 & 11.666 & 42.567 \\
\hline 4 & 1.268 & 5.281 & 58.188 & 1.268 & 5.281 & 58.188 & 2.559 & 10.662 & 53.229 \\
\hline 5 & 1.069 & 4.452 & 62.640 & 1.069 & 4.452 & 62.640 & 2.259 & 9.411 & 62.640 \\
\hline 6 & 0.891 & 3.710 & 66.351 & & & & & i & \\
\hline 7 & 0.834 & 3.474 & 69.824 & & & & & & \\
\hline 8 & 0.771 & 3.214 & 73.039 & & & & & & \\
\hline 9 & 0.657 & 2.735 & 75.774 & & & & & & \\
\hline 10 & 0.631 & 2.628 & 78.402 & & & & & & \\
\hline 11 & 0.552 & 2.301 & 80.703 & & & & & & \\
\hline 12 & 0.496 & 2.067 & 82.770 & & & & & & \\
\hline 13 & 0.483 & 2.012 & 84.782 & & & & & & \\
\hline 14 & 0.444 & 1.851 & 86.633 & & & & & & \\
\hline 15 & 0.443 & 1.844 & 88.477 & & & & & & \\
\hline 16 & 0.392 & 1.633 & 90.110 & & & & & & \\
\hline 17 & 0.363 & 1.511 & 91.621 & & & & & 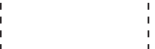 & \\
\hline 18 & 0.350 & 1.458 & 93.079 & & & & & & \\
\hline 19 & 0.340 & 1.416 & 94.495 & & & & & & \\
\hline 20 & 0.333 & 1.389 & 95.884 & & & & & 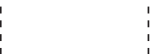 & \\
\hline 21 & 0.279 & 1.161 & 97.045 & & & & & 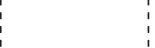 & \\
\hline 22 & 0.272 & 1.135 & 98.180 & & & & & 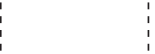 & \\
\hline 23 & 0.243 & 1.012 & 99.192 & & & & & 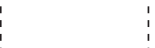 & \\
\hline 24 & 0.194 & 0.808 & 100.000 & & & & & 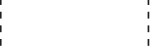 & \\
\hline
\end{tabular}

Metod ekstrakcije: Analiza glavnih komponenti. 
Tabela br. 3: Pouzdanost skale opšteg nivoa samopotvrđivanja u slobodnom vremenu

\begin{tabular}{c|c}
\hline Cronbach's Alpha & Broj ajtema \\
\hline 0.926 & 24 \\
\hline
\end{tabular}

Kao što možemo videti iz Tabele br. 1, prva komponenta, samopotvrđivanje kroz emocionalni boljitak, objašnjava 38,1 \% ukupne varijanse na skali opšteg nivoa samopotvrđivanja; druga komponenta, samopotvrđivanje kroz predanost 9,1 \%; treća, kroz druženje 5,8 \%; četvrta, kroz kreativnost 5,3 \% i peta, kroz proaktivnost 4,5\%. Dok su proaktivnost, kreativnost i druženje prepoznati kao zasebni faktori, predavanje aktivnosti i kreiranje značenja kroz nju su se spojili u jedan faktor (što smo nazvali predanost), kao i prisutvo humora, optimizma i senzualnosti, što smo nazvali emocionalni boljitak.

Rapoređenost mera ajtema na skali opšteg nivoa samopotvrđivanja u slobodnom vremenu možemo videti u Grafikonu br. 1 i u Tabeli br. 4.

Tabela br. 4: Deskriptivne statističke mere skale opšteg nivoa samopotvrđivanja u slobodnom vremenu i podskala

\begin{tabular}{l|c|c|c|c|c}
\hline & N & Minimum & Maksimum & AS & Std. devijacija \\
\hline Samopotvrđivanje kroz emoc. boljitak & 522 & 1 & 5 & 4.17 & 0.660 \\
\hline Samopotvrđivanje kroz proaktivnost & 522 & 1 & 5 & 4.12 & 0.801 \\
\hline Samopotvrđivanje kroz kreativnost & 522 & 1 & 5 & 4.16 & 0.767 \\
\hline Samopotvrđivanje kroz predanost & 522 & 1 & 5 & 4.17 & 0.660 \\
\hline Samopotvrđivanje kroz druženje & 522 & 1 & 5 & 3.75 & 0.998 \\
\hline Opšti nivo samopotvrđivanja & 510 & 24 & 120 & 98.71 & 13.815 \\
\hline
\end{tabular}

Ispitanici se u većoj meri samopotvrđuju kroz emocionalni boljitak, predanost aktivnosti i mogućnost ispoljavanja kreativnosti. Sa stanovišta samopotvrđivanja, u slobodnom vremenu se kao značajno postojanje pozitivnog afekta javlja postojanje smisla ili značenja, odnosno osećaj posvećivanja i apsorbovanosti u odabrane aktivnosti, kao i kreativnost. Manje je značajno druženje i ostvarivanje socijalnih odnosa, što ukazuje na to da se slobodno vreme ne doživljava nužno kao socijalna aktivnost. 
Grafikon br. 1: Deskriptivne statističke mere ajtema na skali opšteg nivoa samopotvrđivanja u slobodnom vremenu

Aritmetička Standardna sredina devijacija

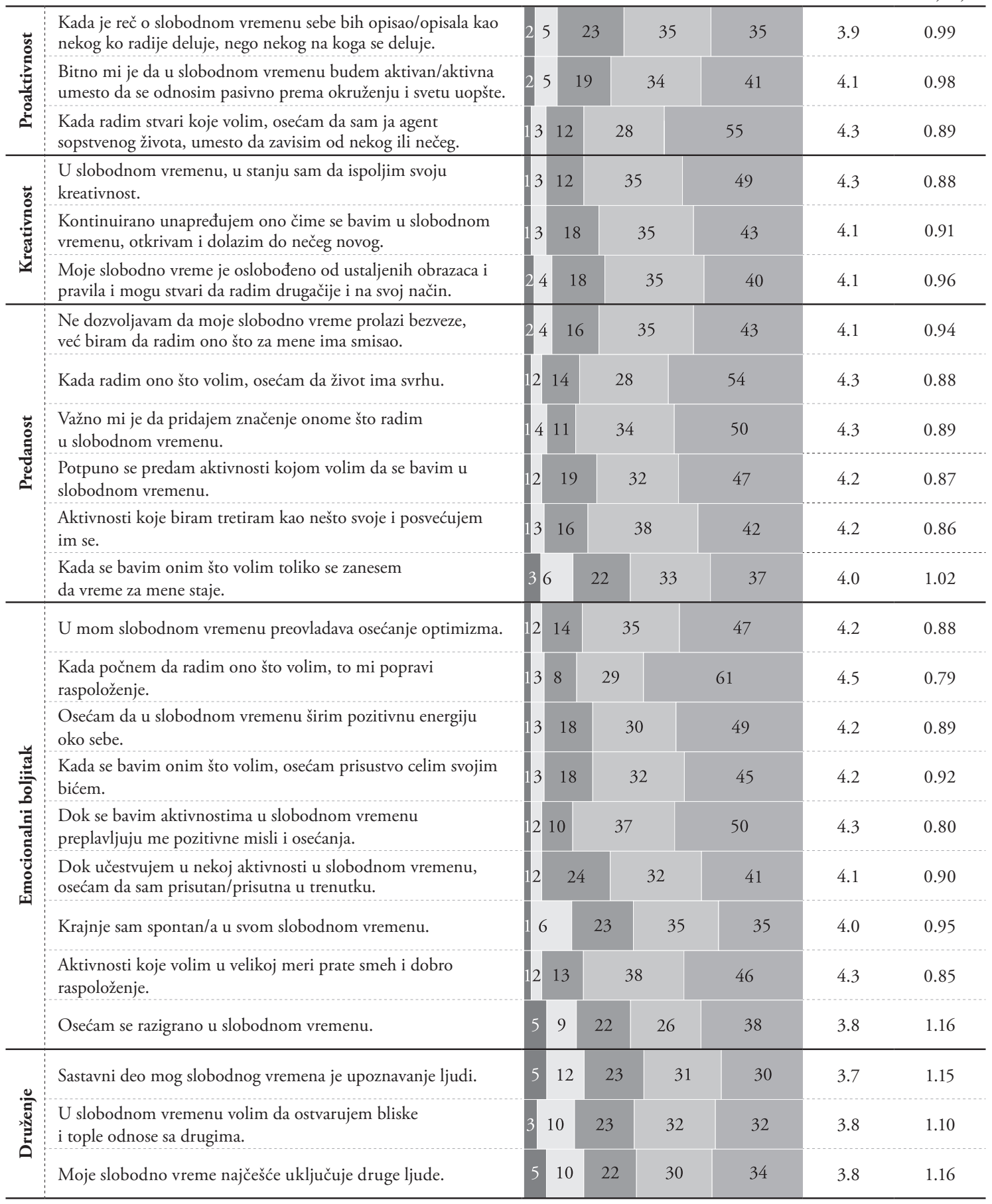


S obzirom da se dosadašnji rezultati odnose na samopotvrđivanje u slobodnom vremenu ispitanika uopšte, interesovalo nas je koliko dokoličarsko obrazovanje, kao jedna od sastavnih aktivnosti njihovog slobodnog vremena, doprinosi tom samopotvrđivanju. Od ispitanika smo tražili da iskažu svoju procenu na petostepenoj skali.

Grafikon br. 2: Opšti doprinos dokoličarskog obrazovanja samopotvrđivanju

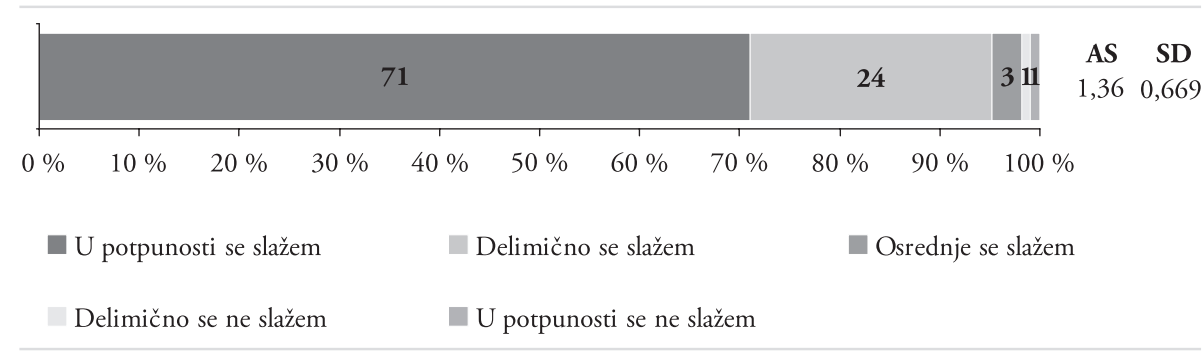

Kao što možemo videti iz Grafikona br. 2, 71 \% ispitanika se u potpunosti slaže da u slobodnom vremenu razvijaju i samopotvrđuju svoju ličnost kroz obrazovanje u koje su uključeni, dok se 24 \% delimično slaže. Možemo zaključiti da je jako mali procenat ispitanika koji smatraju da dokoličarsko obrazovanje ne doprinosi samopotvrđivanju i razvoju njihove ličnosti. Ovo je u skladu sa prethodnim istraživanjima o postojanju univezalne potrebe za samopotvrđivanjem u slobodnom vremenu (Kačavenda-Radić 2003). Tako je i prirodno pretpostaviti da će i obrazovanje doprinositi tome.

Grafikon br. 3: Doprinos dokoličarskog obrazovanja prema dimenzijama samopotvrđivanja

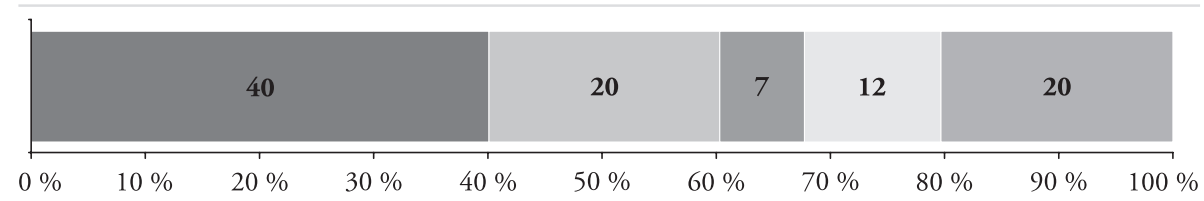

Obrazovanjem u slobodnom vremenu razvijam pre svega svoj intelekt

Najviše razvijam socijalni aspekt ličnosti

U najvećoj meri se razvijam i rastem u emotivnom smislu

Najviše razvijam svoje telo, fizički izgled i fizičku spremnost

Oplemenjujem i razvijam sebe, najviše u umetničkom i estetskom smislu 
Takođe nas je interesovalo u kojim dimenzijama ličnosti se ispitanici više ili manje samopotvrđuju putem participiranja u dokoličarskom obrazovanju. Rezultate možemo videti u Grafikonu br. 3.

Iz Grafikona br. 3 vidimo da najveći procenat (40 \%) ispitanika obrazovanjem u slobodnom vremenu razvija pre svega svoj intelekt. Sledeći po učestalosti navođenja su socijalni aspekt ličnosti i umetnički i estetski aspekt sa po $20 \%$ navođenja. Najmanji procenat (7\%) se razvija u emocionalnom smislu, dok $12 \%$ najviše unapređuje svoj fizički izgled obrazovanjem u slobodno vreme.

Moramo priznati, da nas ovakav nalaz ne čudi, naročito kada su u pitanju dimenzije za koje su se ispitanici opredelili u najvećoj meri i u najmanjoj meri. Naime, to što smatraju da se najviše samopotvrđuju kroz obrazovanje $\mathrm{u}$ intelektualnoj, a najmanje u emotivnoj sferi najverovatnije ima veze sa kartezijanskim dualizmom, odnosno naučenim stavom da je intelekt primaran u odnosu na emocije (Maksimović \& Nikolić Maksić 2013). Takav pogled na odnos mentalnog (kognitivnog) i telesnog (emotivnog) emocije stavlja u drugi plan, te one nisu važne sa stanovišta cilja obrazovanja, osim u slučajevima kada je emotivni razvoj deo obrazovnog sadržaja ili ukorporiran u cilj. Samim tim je ispitanicima teško da vide emocionalnu „korist“ od obrazovanja. Obrazovanje definisano kao sticanje znanja, veština i sposobnosti zaista ističe samo kognitivni aspekt. Matusov (2020) ovako definisano obrazovanje naziva instrumentalnim obrazovanjem i njemu suprotstavlja obrazovanje zasnovano na dokolici (leisurly educatation), koje smatra primerenijim konceptom za post-radno (postwork) i dokoličarsko (leisure-based) društvo budućnosti. Ono neće zameniti instrumentalno obrazovanje, za kojim će i dalje postojati potreba, te koje neće iščeznuti, ali će biti svedeno na neophodno i teći paralelno sa novijim konceptom obrazovanja, koje apeluje na holistički pristup čoveku (uključujući sve aspekte i dimenzije ličnosti). To razume kao zadatak obrazovanja u budućnosti: „Sveti gral obrazovanja je stvaranje posebnih okruženja, kao i pragmatičnih i dokoličarskih aktivnosti koje eliminišu potrebu za instrumentalnim obrazovanjem putem nusproizvoda, nevidljivog učenja, prevare učesnika da se uključe u instrumentalno obrazovanje“" (Matusov 2020: 230).

\footnotetext{
5 "The Holy Grail of education is to create special environments and pragmatic and leisurely activities that eliminate the need for instrumental education via by-product, invisible learning, tricking the participants into instrumental education" (Matusov 2020: 230).
} 
Fizički izgled (telesna dimenzija) je takođe, prema našem mišljenju, u uskoj vezi sa sadržajem i ciljem obrazovanja. Teško da se samopotvrđivanje u ovoj dimenziji odvija u obrazovnim programima čiji to nije cilj ili sadržaj. Povezanost između obrazovno-dokoličarskih sadržaja (njihovog izbora i preferencija u slobodnom vremenu) i dimenzija self-koncepta je potvrđena u ranijem istraživanju (Nikolić Maksić 2009), u smislu da ispitanici biraju da se obrazuju u slobodom vremenu u odnosu na aspekte ličnosti koji su u skladu sa njihovim self-konceptom.

\section{Zaključak}

Kada govorimo o samopotvrđivanju u slobodnom vremenu, može se zaključiti da je opšti nivo samopotvrđivanja na našem uzorku prilično visok. Faktorskom analizom dobijeno je pet faktora samopotvrđivanja: samopotvrđivanje kroz opuštanje, predanost, druženje, kreativnost i proaktivnost. Ispitanici se u većoj meri samopotvrđuju kroz emocionalni boljitak, predanost i kreativnost. Prema dimenzijama samopotvrđivanja, najveći broj ispitanika se samopotvrđuje u kognitivnom smislu, a najmanji u emocionalnom. Ovakavi nalazi u prvi mah mogu delovati kontradiktorno, pogotovu ako imamo u vidu da ispitanici u najvećoj meri smatraju da se samopotvrđuju putem dokoličarskog obrazovanja. Međutim, ispitanici su u prvom slučaju procenjivali samopotvrđivanje u slobodnom vremenu uopšte, dok su u drugom davali svoju procenu samopotvrđivanja kroz obrazovanje. Očigledna je ipak razlika u razmišljanju, gde se slobodno vreme povezuje sa emocionalnim komponentama samopotvrđivanja, dok se obrazovanje u mnogo manjoj meri povezuje sa emocionalnom dimanzijom. To pokazuje da, iako se obrazovanje očigledno visoko vrednuje (i) kada je u pitanju slobodno vreme, ono se ipak primarno ne povezuje sa dimenzijama koje se pripisuju slobodnom vremenu ili se od slobodnog vremena zahtevaju (kao što su u našem slučaju one koje ukazuje na pozitivan afekat, a koje su oblikovale emocionalnu komponentu samopotvrđivanja). Kao što smo objasnili, obrazovanje se prvenstveno povezuje sa kognitivnom dimenzijom, što se može pripisati tradicionalnom usmerenošću obrazovanja na intelekt. U tom smislu, postavlja se kao značajno pitanje: na koji način organizovati dokoličarsko obrazovanje? Kakve implikacije ovaj nalaz ima u odnosu na njegovo zasnivanje u 
praksi, ukoliko imamo u vidu da je za samopotvrđivanje u slobodnom vremenu važan emocionalni boljitak, dok se putem obrazovanja u slobodnom vremenu emocionalna dimenzija samopotvrđivanja ne javlja kao najvažnija? Površno gledano, taj podatak i ovakvo pitanje ne moraju imati nikakve nužne intervencije kao posledicu. Na njih se jednostavno može gledati kao na mogućnost da obrazovanje doprinosi slobodnom vremenu u dimenzijama koje su mu u manjoj meri imanentne. Međutim, niti je slobodno vreme lišeno ozbiljnosti i kognitivnog potvrđivanja niti obrazovanju nedostaju uživanje i pozitivni afekat. Čini nam se da bi dokoličarsko obrazovanje (naročito ono koje se tiče pripremanja odraslih za slobodno vreme) moralo da razvija ideju o obrazovnim aktivnostima kao igri (Nikolić Maksić \& Ljujić 2012; Kjølsrød 2018), naročito augmentativnoj igri (Stebbins 2020), zabavi (Son et al. 2020), performativnosti i improvizaciji (Nikolić 2019), koje uključuju čitav organizam u svoj svojoj ukupnosti. Za početak, samo dokoličarsko obrazovanje bi trebalo organizovati na principima razigranosti, uživanja, duboke involviranosti, predanosti, aktiviranja, zabave i kreativnosti (Nikolić 2015). Dakle, svemu onome što slobodno vreme predstavlja i podrazumeva. Takvo obrazovanje odraslih nije manje vredno ili manje ozbiljno od onog koje se ne povezuje sa slobodnim vremenom ili se ne odvija u slobodnom vremenu. Naprotiv, to je obrazovanje koje je po meri čoveka i apeluje na njega kao na celovito biće, koje ima kapacitet i tendenciju da tokom celog života raste, usavršava se i razvija. 


\title{
Education and Self-Affirmation of Adults in Leisure
}

\begin{abstract}
The paper presents the results of research related to the examination of the relationship between education that adults undertake in their free time, on the one hand, and the scope, degree and manner in which they self-affirm in their leisure time on the other. By self-affirmation we mean the realization or actualization of oneself as a single being through the degree of satisfaction of various needs relevant from the point of view of personality integration. The notion of self-affirmation understood in this way, viewed in the context of leisure time, represents a constituent of the quality of leisure time in adulthood. Specifically, this paper presents the results related to the examination of the general level of self-affirmation in leisure time, as well as the contribution of educational activities to self-affirmation in leisure time. The most significant of them advocate the existence of a universal need for self-affirmation in leisure time. More specifically, they concern self-affirmation in the context of emotional well-being, commitment to the activities, in which adults choose to engage themselves in their leisure time and creativity. According to the dimensions of self-affirmation, the largest number of surveyed participants of educational activities is self-affirmed in the cognitive, yet the smallest number, in the emotional sense.
\end{abstract}

Keywords: leisure, leisure adult education, self-affirmation in leisure, dimensions of self-affirmation. 


\section{Literatura:}

Cohen, L., Manion, L. \& Morrison, K. 2000. Research Methods in Education. 5th ed. London: Routledge Falmer.

Csíkszentmihályi, M. \& LeFevre, J. 1989. Optimal Experience in Work and Leisure. Journal of Personality and Social Psychology, 56(5), pp. 815-822.

Csíkszentmihályi, M. 1999. If We Are So Rich, Why Aren't We Happy? American Psychologist, 54(10), p. 821.

Godbey, G. 2008. Leisure in Your Life: New Perspectives. State College, PA: Venture Publishing, Inc.

Kačavenda-Radić, N. 1985. Obrazovanje kao činilac korišćenja slobodnog vremena zaposlenih. Doktorska disertacija. Beograd: Filozofski fakultet.

Kačavenda-Radić, N. 1989. Slobodno vreme i obrazovanje. Beograd: Zavod za udžbenike i nastavna sredstva.

Kačavenda-Radić, N. 1992. Refleksije (o/i) slobodnog vremena. Beograd: Institut za pedagogiju i andragogiju, Filozofski faklutet, Univerzitet u Beogradu.

Kačavenda-Radić, N. 2003. Sutiability and Education of the Population for Incoming Tourism. In: Đorđević, J., ed. The Development and Potentials of Ecoturism on Balkan Peninsula (Vol. II). Belgrade: Stručna knjiga, (pp. 21-31).

Kačavenda Radić, N., Nikolić Maksić, T. i Ljujić, B. 2011. Kvalitet dokoličarskog i komunikaciono-medijskog obrazovanja odraslih. U zborniku: Kačavenda Radić, N., Pavlović-Breneselović, D. i Antonijević, R. ur. Kvalitet u obrazovanju. Beograd: Institut za pedagogiju i andragogiju Filozofskog fakulteta Univerziteta u Beogradu, str. 73-97.

Kjølsrød, L. 2018. Leisure as source of knowledge, social resilience and public commitment: Specialized play. Springer.

Kleiber, D. A. 1999. Leisure Experience and Human Development: A Dialectical Interpretation. New York, NY: Basic Books.

Maksimovic, M. \& Nikolic Maksic, T. 2013. Body Empathy and Counseling Relationship - Andragogical Perspectives. In: Despotovic, M. and Hebib, E., eds.: Contemporary Issues of Education Quality. Belgrade: Institute for Pedagogy and Andragogy, pp. 279-290.

Matusov, E. 2020. Envisioning Education in a Post-Work Leisure-Based Society: A Dialogical Approach. Springer Nature.

Neulinger, J. 1974. The Psychology of Leisure: Research Approaches to the Study of Leisure. Springfield, IL: Charles. C. Thomas.

Neulinger, J. \& Breit, M. 2009. Attitude Dimensions of Leisure: A Replication Study. Journal of Leisure Research, 41(3), 361. 
Nikolić Maksić, T. 2009. Self-koncept i obrazovanje odraslih u slobodnom vremenu. Magistarska teza. Beograd: Filozofski fakultet.

Nikolić Maksić, T. \& Ljujić, B. 2012. O igri u odraslom dobu i njenim obrazovnim implikacijama. Andragoške studije, 2, str. 105-119.

Nikolić Maksić, T. 2015. Obrazovanje kao činilac kvaliteta slobodnog vremena odraslih. Doktorska disertacija. Filozofski fakultet, Univerzitet u Beogradu.

Nikolić Maksić, T. 2017. Obrazovne karakteristike i konzistentnost u obrazovnodokoličarskom ponašanju odraslih. Obrazovanje odraslih, str. 75-95.

Nikolić, T. 2019. Reći „da, i...“ učenju: obrazovni proces kao improvizacija. Andragoške studije, 2, str. 93-112.

Preht, R. D. 2011. Ko sam ja - i ako jesam, koliko sam? Beograd: Mono i Manjana.

Son, J., Weybright, E., Janke, M. \& Payne, L. 2020. Evolving Societal Contributions of Leisure Education. In Positive Sociology of Leisure . Palgrave Macmillan, Cham, pp. 239-257.

Stebbins, R. A. 2020. The serious leisure perspective: A synthesis. Springer Nature. 